\title{
Users, User-Friendliness and Projected Uses of Isichazamazwi SesiNdebele: An Analysis*
}

\author{
Langa Khumalo, Department of Linguistics, University of KwaZulu-Natal, \\ Durban, Republic of South Africa (la_nga@yahoo.co.uk)
}

\begin{abstract}
This article discusses the first-ever monolingual general Ndebele dictionary, Isichazamazwi SesiNdebele (henceforth the ISN) within the context of the history of lexicography and the compilation of dictionaries in Ndebele. It further assesses the scope of the dictionary with regard to its structure. It also discusses decisions taken by the editors during the writing of the ISN in an attempt to compile a user-friendly dictionary primarily aimed at secondary schools and the general Ndebele population. The assumptions of the editors, coming from a non-existing lexicographic tradition, were mainly based on their experiences and intuitions as Ndebele mother-tongue speakers, educators and language practitioners. The article also accounts for four major uses of the dictionary.
\end{abstract}

Keywords: TARGET USER, USER-FRIENDLY, CORPUS, FRONT MATTER, BACK MATTER

Opsomming: Gebruikers, gebruikersvriendelikheid en die beplande gebruike van Isichazamazwi SesiNdebele: 'n Ontleding. Hierdie artikel bespreek die heel eerste eentalige algemene Ndebelewoordeboek Isichazamazwi SesiNdebele (voortaan die ISN) binne die konteks van die geskiedenis van die leksikografie en die samestelling van woordeboeke in Ndebele. Dit beoordeel verder die omvang van die woordeboek met betrekking tot sy struktuur. Dit bespreek ook besluite wat deur die redakteurs van die ISN geneem is tydens die skryf van die ISN in 'n poging om 'n gebruikersvriendelike woordeboek saam te stel wat primêr gerig is op sekondêre skole en die algemene Ndebelebevolking. Die aannames van die redakteurs wat van 'n niebestaande leksikografiese tradisie kom, is hoofsaaklik gebaseer op hul ervarings en intuïsies as moedertaalsprekers, opvoeders en taalpraktisyns. Die artikel verantwoord ook vier hoofgebruike van die woordeboek.

Sleutelwoorde: TEIKENGEBRUIKER, GEBRUIKERSVRIENDELIK, KORPUS, VOORWERK, AGTERWERK

\section{Historical Background}

Hadebe (2002) has given a detailed history of lexicographic work in the Ndebele language. From his account, it is clear that the Ndebele language has a

\footnotetext{
This article is a revised and updated version of a paper presented at the Sixth International Conference of the Linguistic Association of SADC Universities, held at the University of Botswana, Gaborone, Botswana, 6-8 August 2001.
} 
short lexicographic history. Until the publication of the ISN there was no monolingual Ndebele dictionary. There was only one bilingual English-Ndebele dictionary, A Practical Ndebele Dictionary by Pelling (1971), which has about 4500 entries. However, one of the earliest Ndebele lexicographic works was compiled by a missionary of the London Missionary Society, W.A. Eliot. It appeared in 1897, with the title Dictionary of the Tebele and Shona Languages. Later he published what can be considered the first bilingual Ndebele-English dictionary which used the early Ndebele orthography. Changes in the Ndebele orthography would take place in the 1930s. Another early work of that period was a word list compiled by a British South Africa Police trooper, which was published in Cape Town in 1903 under the title of Matebele and Makalaka Vocabulary: Intended for the Use of Prospectors and Farmers in Mashonaland (see Chimhundu 1992: 18).

Pelling (1971) has been the only dictionary in the current Ndebele orthography until the publication of the ISN in 2001. There is not much information either in the front or the back matter of the dictionary to indicate the principles followed in the compilation of this bilingual dictionary. It has been observed by Hadebe (2002) that Pelling's dictionary mainly updates the orthography while its contents are chiefly a revision of Eliot's dictionary. While the ISN is based on different principles, Hadebe admits that the background set by Pelling's dictionary cannot be ignored, especially in so far as the standardization of the Ndebele language is concerned.

Hadebe (2002) further observes that the absence of the publication of dictionaries does not mean the absence of lexicographic work of one kind or another. Some dictionary projects were initiated but never finished while others were finished, but for various reasons, the manuscripts were never published. There are two cases in point, the dictionary project by S.J. Mhlabi, then Senior Language Assistant in the African Languages and Literature Department of the University of Zimbabwe, and that of G. Sibanda also from the University of Zimbabwe. Mhlabi's work is a bilingual Ndebele-English dictionary in the form of a complete manuscript, with its cards catalogued. This project was supervised by the then Professor of African Languages, George Fortune, who retired before the manuscript could be sent for publication. Sibanda's work was a privately funded project initiated by the Ndebele Language Committee. According to Hadebe's account, the completed work was sent to the publishers and, after having received some comments for further editing, the manuscript disappeared without being published.

The current lexicographic work on Ndebele by the African Languages Research Institute (ALRI), previously the ALLEX Project, at the University of Zimbabwe, Harare, is being documented through annual reports, so that it is easier to gather information on the progress of this work than it was for other previous projects. The ALLEX Project, the brainchild of Professor Herbert Chimhundu, was generously funded by NUFU (Norwegian Universities' Committee for Development Research and Education) through the development of a North-South cooperation. This project was aimed at producing monolingual 
dictionaries and glossaries in the African languages of Zimbabwe. This was a large collaborative research project involving more than thirty academics, students, technical staff and other support staff at the University of Zimbabwe and computer and lexicography specialists from the University of Oslo in Norway and the University of Gothenburg in Sweden.

The research that led to the publication of the ISN resulted in the questioning of a number of tenets that had been taken for granted about the Ndebele language. For instance, it has been generally assumed that the Ndebele language does not have varieties (Chimhundu 1993: 59) or that the variation was insignificant. Yet, the corpus of oral material has revealed some variations in speech behaviour according to the geographical sources of this material (Hadebe 2002). It is, however, clear from the foregoing that Ndebele lexicography has a short history.

\section{The General Scope of the ISN}

The ISN is the first-ever monolingual dictionary in the Ndebele language. The title of the dictionary (Isichazamazwi SesiNdebele, literally, the explainer of words in Ndebele) already indicates that it is a dictionary of Ndebele in Ndebele, in which the resources of the language are used for the first time lexicographically to analyze and describe itself. As stated above, until the publication of the ISN, the Ndebele people were using Pelling's bilingual Ndebele-English dictionary.

The ISN is a medium-sized, general-purpose dictionary designed to be inexpensive and easy to handle so as to be accessible to secondary school pupils and the general Ndebele population. According to commonly accepted modern standards, it is well printed, with the utilization of different kinds of typographical conventions, which demonstrates the movement from headword to synonyms in the treatment of each major entry in the dictionary. The components of a typical major entry are: the headword, in large bold lower-case roman letters; the type of word in question (i.e. grammatical information), described by an abbreviated label in standard lower-case roman letters; a number, in the case of a noun, indicating the class to which it belongs; an explanation of the meaning or meanings in lower-case roman letters, with the headword, when referred to, printed in italics; an illustrative example or examples given in italics showing the headword in context; and finally, synonyms, printed in italics under the rubric FAN, an abbreviation for amagama alengcazelo ezifanayo, which means 'similar forms'. The following is an example of an entry in the ISN:

indwangu bz 9. Indwangu yinyamazana elesiphongo, ifana lenkawu kodwa yona inkulu. Indwangu ziqede umumbu emasimini. FAN imfene.

(baboon n. 9. A baboon is an animal that has a forehead, it is like a monkey but is bigger. Baboons ate all the maize in the fields. SYN imfene.)

Tone markings of each headword were not provided throughout the diction- 
ary. This was a deliberate decision taken by the editors after considering both the merits and the demerits of omitting it. Whereas Ndebele like most Bantu languages is tonal, the omittance of tone marking therefore excludes the complete grammatical representation of the language. It was argued that, since the ISN is a monolingual dictionary, a mother-tongue speaker would hardly require tone marking of two or more homonyms, for the context can easily disambiguate them. Further, it was considered that the main target users, i.e. secondary school pupils, are not at a level where they would have been introduced to such grammatical detail, so that it would have caused complications. As a result, it was decided to include tone marking, together with the phonetic transcription of each headword, in the planned Advanced Ndebele Dictionary, which will be a successor to the ISN with target users anticipated to be mainly college and university students and language practitioners.

The ISN has a total of 20008 headwords. In order to make the selection of headword entries as widely representative of the culture of the Ndebele people as possible within the compass of a general-purpose, medium-sized dictionary, the editors ensured that the collection of material was done as widely as possible. The four provinces where Ndebele is predominantly spoken were identified, that is, Matebeleland South, Bulawayo, Matebeleland North and the Midlands provinces. Areas where research was carried out were in secondary schools, colleges and universities, especially for terms covering language and literature, the media, sports and games, religion, trade and commerce, law and administration. Research in rural areas covered terms dealing with the traditional life and the rural livelihood of the Ndebele people, including aspects such as hunting, farming, marriage ceremonies, traditional dances and chief's courts. Oral interviews were carried out and books (covering different genres like novels, drama, poems and text books) were collected to create a corpus from which to draw headwords, definitions from contextual usage and examples. Thus, the ISN is a corpus-aided dictionary, using "language that has actually come from the mouths or pens of ... speakers themselves", as Fortune (2001: 122) puts it.

\section{Target Users of the ISN}

As has been stated above, the ISN is a general dictionary. This means that it is a general-purpose reference work, appealing to a wide spectrum of users. The work has a four-fold objective. The first is to provide a medium-sized dictionary aimed at teachers and students at secondary school. This is consistently emphasized because it determines the size of the dictionary. A medium-sized dictionary, easy to handle, was thought to be appropriate, for it would be cheaper, making it affordable to the target users. The dictionary was projected to assist teachers and students to understand and teach the structure of their language through the provision, for the first time, of a technical terminology in Ndebele, describing its linguistic features. Teachers and students of Ndebele 
are more likely to need to consult a dictionary than other users and to use its contents in the course of their daily lives as well as to convey its contents to others (Fortune 2001: 122).

The second objective is to facilitate the use and understanding of Ndebele for mother-tongue speakers. For young children, the mother tongue is the first means of communication and the chief instrument for interpreting and understanding the world in which they live. Without mastery of language, there can be no mastery of life. For school children in particular, the mother tongue is important. Children acquire knowledge very rapidly if they are allowed to build on what they already know. All children bring their mother tongue to school. The ISN hopes to impact positively on schoolchildren facing the difficulty of receiving instructions in English, currently the only official language in Zimbabwe.

For the ordinary reader, such a reference work can provide, in an easily understandable manner, the meaning, use, and function of words which would not be so fully grasped if conveyed in, and then translated from, a foreign language as has been the case hitherto. The dictionary contains the language these users utilize every day; it reflects their traditional, rural and even contemporary use of language. "Now sifted and sorted, linguistically analysed and selfdefining, it is handed back to them to put to use," says Fortune (2001: 122). It mirrors, as it were, their lives and reflects it.

The third objective is to provide a unitary language, which is the property and inheritance of all. Although the Ndebele people believe that Ndebele does not have regional variants, evidence from the corpus suggests otherwise. Thus contributions from all Ndebele-speaking regions were sought to add to the vocabulary of the language, particularly the vocabulary that has come as a direct influence from the "dominated so-called minority groups" like Venda, Sotho and Kalanga. This resulted in a good deal of synonymity. As far as synonyms were concerned, widely-used forms were treated fully with definition and exemplification, while forms with a narrower distribution were entered as headwords, receiving a shorter treatment by referring users to the main entry. This procedure is a straightforward and economical way of promoting the unification of the language, while reflecting its inner differentiation of various regional uses.

The fourth objective, which Fortune (2001) refers to as the "animating heart of the ALLEX project" is to promote the status and use of the language. The dictionary, it is hoped, will help to make people use it fittingly in widening areas of life, and to value it as conferring self-respect and a means towards an improved and developed standard of life. This will be achieved by a greater participation in affairs at all levels through the medium of the mother tongue. It is envisaged that the Ndebele language will be capable of developing into a medium of expression and communication which enables the Ndebele people to carry out their affairs in all spheres of life in their mother tongue and to communicate at all levels of their concerns, aims and techniques for national development. It therefore wants to make a contribution to a change of policy 
for Ndebele to be recognized as an official language in Zimbabwe. Hitherto it has remained inferior to English, which is the only official language.

Related to the fourth aim is the fact that the ISN will contribute towards language raising. According to Chimhundu and Gronvik (2007: 1), language raising is a term coined and used in Norway around 1850, describing an effort to "create a standard language (from the vernacular), cultivate it and have it accepted in the language community where it belongs". Language raising refers to all struggles and attempts to develop a literary language from the basis of a vernacular. Once the language has been sufficiently developed, it assumes wider functions in education, industry, commerce and law. It is therefore envisaged that the ISN is to contribute to the conducting of all kinds of education in the mother tongue. This is the medium through which education is most effective and personalized, and through which it can best permeate through society, raising the level of skills and abilities with a resultant higher standard of life. The ISN is a firm basis upon which to build.

\section{User-Friendliness of the ISN}

User-friendliness can be viewed in two ways. It can pertain either to the size and cover format of the dictionary or to the presentation of the definitions and their examples. The ISN is user-friendly because, being not too bulky, it is easy to handle. It is medium-sized and therefore big enough to cover a wide variety of terms. It has a large cover format. The fonts and spacing of the text fits more elegantly and more legibly within its wider margins. This clear layout and presentation simplify it for the user to access information in the dictionary.

Even to general users, it is basic knowledge that a dictionary lists words and their meanings. Consequently, the importance of a definition which is an intrinsic component of a dictionary cannot be overemphasized. In fact, defining is probably one of the most important exercises in the dictionary-making process. It is because of this rigorous process that users can interact with a particular word, discovering its meaning as explained in each definition.

This makes defining formats, a format being "the way in which something is arranged and presented" (Sinclair 1990: 218), crucial in composing definitions. Defining formats are pertinent insofar as they help the editors to write clear, concise, specific, systematic and culturally relevant definitions that make dictionaries user-friendly (Khumalo 2002: 266). These formats are geared towards providing editors with certain guidelines to follow in constructing a definition, hence contributing to consistency in the treatment of related sets of headwords. This view is accentuated by Gellerstam's (1993: 47) observation that "the development of definition formats is advantageous in that once a particular format has been agreed upon, a number of words can be defined with it". The guiding principle of the editors throughout the compilation of the ISN was, therefore, to produce a user-friendly dictionary.

The editors of the ISN used the Collins Birmingham University Interna- 
tional Language Database (COBUILD), that is, the COBUILD-type format for their definitions. Defining is one of the most important processes in dictionary making because it is important for users to know the meanings of words so that they can use the words in a prescribed manner in both spoken and written language. A dictionary is prescriptive insofar as it distinguishes the formal and colloquial uses of any particular word.

The following are COBUILD defining formats as outlined by Hanks (1987) and Moon (1987):

(a) The headword should appear in the definition.

(b) The headword should be shown in a typical context of common usage because "context disambiguates" (Hanks 1987: 125).

(c) Definitions should consist of full sentences.

(d) Explanations should consist of two parts, with the first part showing the word in use and the second one explaining the meaning.

(e) The format should suggest a preference rather than a restriction.

For COBUILD, a good definition should be short, culturally relevant and consistent with others of its type, using superordinate terms (Hanks 1987: 118). When a definition has been made simple and familiar, it thus helps the dictionary as a whole to become user-friendly. The COBUILD system demonstrates a marked departure from traditional lexicography which, according to (Hanks 1987: 117), "heavily relies on the use of parentheses whose function is not based on the standard usage of ordinary written English". The idea was to create a "dictionary as prose" (Hanks 1987: 118). COBUILD has therefore abandoned the use of parentheses because they are not user-friendly. Considerable sophistication is required on the part of dictionary users to work out what precisely is meant by each set of parentheses. This was an important view to consider, because the ISN was a first monolingual dictionary in Ndebele, which had no previous lexicographic tradition for the users to have developed the requisite sophistication. Therefore the COBUILD formats proved very useful in achieving user-friendliness, which was the editorial team's goal.

Evident characteristics of the COBUILD system of defining formats are: definitions should be as natural as possible, should project typical usage of a headword, and should be easy to understand. These guidelines were instrumental for the editors in organizing, crafting and presenting user-friendly definitions. In the ISN, each definition consists of a complete sentence, so that the user is shown the word as it appears in natural language use. Such a definition illustrates both the typical grammatical context and the typical use of the word. From the user's point of view, this method of definition is particularly useful for an inflecting language like Ndebele where headwords are not necessarily orthographic words. A good example is the following:

-thenga sz mwa. Nxa uthenga ulutho uyabe ulukhokhela imali ukuze uluthole.

(buy transitive verb. If you are buying something, you will be taking out money for it so that you can have it.) 
The definitions present "the typical case" in such a way that the meaning is made clear. This enables dictionary users to become familiar with its use and further applications, so that they can employ it in sentences of their own. When the definition is perceived to be insufficient in itself, then an illustrative example is provided to clarify it further, always by way of a complete sentence extracted from the corpus which provides natural language in use.

\section{Examples in the ISN}

As a source of data for linguistic analysis, corpus work has played an important role in linguistic research, and an even more important role in lexicography. Kennedy (1998: 88) observes that a linguistic corpus, in whatever form, is important as a basis for more accurate and reliable descriptions of how languages are structured and used. Sinclair (1991: 171) defines a corpus as "a collection of naturally-occurring language text, chosen to characterize a state or variety of a language". According to Renouf (1987: 1), it is a body of collected texts, of the written or spoken word, which is stored and processed on computer for the purposes of linguistic research. Because of the importance of the corpus in any dictionary-making process, i.e. for purposes of headword and sense selection and obtaining examples of natural language usage, the ISN editors had collected a corpus of about a million running words before starting to compile the dictionary. The Ndebele corpus currently stands at around two and half million words. The editors greatly benefited from the Ndebele corpus while writing definitions for the ISN.

Each word occurs in its own special environment. This is referred to as the cotext. By studying the cotext, the editors managed to work out the various senses of each word in these different environments. This made a seemingly difficult task, which may take time when intuition is used, simple by employing the corpus to show up various instances of a particular word using a software program. Senses such as those listed below were identified through this quick method:

umuzi bz 3. Umuzi yindawo kumbe ikhaya lapho okuhlala kona abantu.

(home n. 3. A home is a place or a dwelling where people live.)

umuzi bz 3. Umuzi lichatha elimnyama emzimbeni umuntu azalwa elalo.

(birthmark n. 3. A birthmark is a coloured mark on the skin, which is there from birth.)

umuzi bz 3. Umuzi butshani obude obukhula ikakhulu emaxhaphozini.

(umuzi n. 3. Umuzi is a type of grass which grows on marshy ground.)

Concordances provide lexicographers with real text examples. It demonstrates a particular word in a typical sentence in agreement with other naturally cooccurring words. According to Sinclair (1991), examples from concordances have a status which made-up examples do not have, because they are typical. 
The ISN editors obtained the examples for most of their headwords from the corpus, which provided the dictionary with more "natural" examples. These examples were viewed as a very important component of the definition. The ISN editors resolved that

(a) since examples are part of the definition, they should be used only when they serve to complement the definition by clarifying the headword, that is, to illustrate meanings or uses only when it is necessary,

(b) only one example should be given for reasons of saving space, and

(c) they should also be short like the definitions.

These decisions were meant to benefit the users by making the dictionary more accessible and user-friendly. In many cases, the definition of a headword is so informative that there is no need for a further sentence to use as an illustrative example. However, when the definition may not cover all the senses inherent in a headword, providing an illustrative example clarifies the meaning of the word, enabling users to learn its use and further applications so that they can employ it in sentences of their own.

\section{The Front Matter and the Back Matter}

The introduction to the ISN, the front matter, gives, among others, the following important background information: (a) the history of the Ndebele people, their identity, the sociolinguistic factors that have influenced their language and the history of Ndebele orthography, (b) the state of the Ndebele corpus, (c) a brief description, i.e. a mini-grammar, of the structure of the Ndebele language, (d) the defining formats used for different parts of speech such as nouns, verbs, ideophones and adjectives, and (e) the metalanguage list, or the technical language the editors employ, partly derived from current use and partly specifically devised. The latter is presented in three columns giving (a) the abbreviations, (b) the Ndebele terms in full, and (c) the English equivalents. For example:

$$
\begin{array}{lll}
\mathrm{bz} & \text { ibizo } & \text { noun } \\
\mathrm{lw} & \text { ulwangeni } & \text { palatal }
\end{array}
$$

The presentation of the alphabetically arranged terms in three columns provides an index for cross-reference. This, together with a comprehensive minigrammar, is expected to help towards the teaching of Ndebele in Ndebele in secondary schools. Hitherto Ndebele has been without a grammar book describing the structure of Ndebele in Ndebele. It is in the field of linguistics and literature that the first creation of technical terminology has been made.

The back matter completes the structure of the dictionary. It is additional information inserted at the back of the dictionary, which the editors felt was useful and enriching to the target users. The back matter covers technical terms 
in mathematics and government institutions, including judiciary information. It also covers a variety of cultural information. Most of the terminology is currently in use in Ndebele, but has not been formally presented, this being an attempt by the editors to standardize it.

\section{Conclusion}

The following points can be noted in conclusion: (a) the ISN is the first-ever monolingual Ndebele dictionary, (b) it is a medium-size, general-purpose dictionary drawn from language used in the everyday lives of the Ndebele people, (c) it covers the history of the Ndebele people and their culture, past and present (in the historical and contemporary sense), both in the front and the back matter, and (d) the main target users, learners and educators, will benefit not only from the definitions in the word list but also from the mini-grammar in the front matter. Finally, it can be said that a serious attempt was made to produce a user-sensitive, user-friendly and user-driven work for its envisaged target users.

\section{References}

Chimhundu, H. 1992. Standard Shona: Myth and Reality. Crawhall, N.T. (Ed.). 1992. Democratically Speaking: International Perspectives in Language Planning: 77-88. Cape Town: National Language Project.

Chimhundu, H. 1993. The Status of African Languages in Zimbabwe. Southern African Political and Economic Monthly 7(1): 57-59, October.

Chimhundu, H. and O. Gronvik. 2007. The Allex Project and Language Raising in Zimbabwe. A paper presented at the NUFU Dissemination Conference, Bergen, Norway, 5 June 2007.

Eliot, W.A. 1897. Dictionary of the Tebele and Shona Languages. Cape Town.

Fortune, G. 2001. Book Review: Duramazwi reChishona. Zambezia 28(1): 121-127.

Gellerstam, M. 1993. The Use of the Corpus. Chimhundu, H. (Ed.). 1993. Report on the African Languages Lexical (ALLEX) Project Planning and Training Workshop: 45-56. Harare: University of Zimbabwe.

Hadebe, S. 2002. The Standardisation of the Ndebele Language through Dictionary-Making. D.Phil. Thesis. Harare/Oslo: University of Zimbabwe/University of Oslo.

Hadebe, S. et al. (Eds.). 2001. Isichazamazwi SesiNdebele. Harare: College Press.

Hanks, P. 1987. Definitions and Explanations. Sinclair, J.M. (Ed.). 1987: 115-136.

Kennedy, G. 1998. An Introduction to Corpus Linguistics. London/New York: Longman.

Khumalo, L. 2002. Defining Formats and Corpus-based Examples in the General Ndebele Dictionary, Isichazamazwi SesiNdebele. Lexikos 12: 264-274.

Moon, R. 1987. The Analysis of Meaning. Sinclair, J.M. (Ed.). 1987: 86-103.

Pelling, J.N. 1971. A Practical Ndebele Dictionary. Revised Edition. Harare: Longman Zimbabwe.

Renouf, A. 1987. Corpus Development. Sinclair, J.M. (Ed.). 1987: 1-40.

Sinclair, J.M. 1991. Corpus, Concordance, Collocation. Oxford: Oxford University Press.

Sinclair, J.M. (Ed.). 1987. Looking Up: An Account of the COBUILD Project in Lexical Computing and the Development of the Collins COBUILD English Language Dictionary. London/Glasgow: Collins ELT. 